\title{
Reappearance of Aedes aegypti (Diptera: Culicidae) in Lima, Peru
}

\section{Carlos Sevilla Andrade*, Abraham G Cáceres/ ${ }^{+}$, Aldo Vaquerizo**, Sergio Ibañez-Bernal***, Lourdes Sulca Cachay**}

\begin{abstract}
Sección de Entomología *Laboratorio de Parasitología, Instituto de Medicina Tropical "Daniel A. Carrión" **Facultad de Ciencias Biológicas, Universidad Nacional Mayor de San Marcos, Jr. José Santos Chocano No 199, Lima 1, Perú ***Departamento de Entomología, Instituto de Ecología, Veracruz, México
\end{abstract}

We report here the reappearence of Aedes aegypti in the Rimac district, and summarize the history of this mosquito species in Peru since its first detection in 1852.

On March 172000 were found Ae. aegypti and Culex quinquefasciatus in Mariscal Castilla town, Flor de Amancaes, San Juan de Amancaes, El Altillo and Santa Rosa in the Rimac district, Lima Province.

Key words: Aedes aegypti - Culicidae - Diptera - Lima - Peru

Aedes aegypti was first detected in Peru in 1852. It is believed that it was introduced into Peru through its northern border, from the neighboring region of Guayaquil, Ecuador. Ae. aegypti became progressively established along the northern and central Peruvian coast, extending its distribution to Tacna, in the southern region of Peru (Griffitts 1934). In 1905, Barton reported the occurrence of Ae. aegypti in the harbor of Callao, Department of Lima. These findings set in motion the first Ae. aegypti control campaign in Peru (Roe 1924).

In 1938, the results of a nationwide survey showed that Ae. aegypti was established in 191 localities, spread over 11 Departments. It was estimated that Ae. aegypti had expanded its range over an area of $638,000 \mathrm{~km}^{2}$ (Oficina Sanitaria Panamericana 1948, Neyra \& Sipán 1983). As a result of the Ae. aegypti control program, the Peruvian Ministry of Health, under the advisement of the Pan-American Health Office (PAHO), announced that Ae. aegypti had been erradicated from the country in 1958 (Severo 1958). The control campaigns were replaced by local surveillance programs until 1964 when they were discontinued. Based on PAHO recommendations, surveillance programs were re-established in 1972. Unfortu-

\footnotetext{
${ }^{+}$Corresponding autor. Fax: +51-1-254.5656. E-mail: acaceres31@hotmail.com

Received 10 October 2000

Accepted 22 March 2001
}

nately, these programs were progressively less organized.

Ae. aegypti was again detected in Peru in 1984, when personnel of the National Control Program for Malaria and other Metaxenic Diseases (Ministry of Health) reported the capture of Ae. aegypti in the Department of Loreto. Based on the 1984 surveillance, it had become widely established in the towns of Iquitos and Yurimaguas (Departament of Loreto) and Pucallpa (Department of Ucayali) suggesting, that although it went unnoticed, the reestablishment of Ae. aegypti in the region must have occurred a few years earlier. In 1985, this mosquito was found in Nauta and Contamana (Department of Loreto) and by 1986, had expanded its range to the Departments of San Martin (Tarapoto) and Huanuco (Tingo María). Thereafter, the occurrence of Ae. aegypti was reported in some Provinces from Junin, Pasco, Tumbes, Piura, Lambayeque, La Libertad, Amazonas, Cajamarca and Madre de Dios.

During the two first weeks of March 2000, residents of Flor de Amancaes and San Juan de Amancaes (Rimac district, Lima) complained about being bitten by mosquitoes during day and night. On March 17, larvae and pupae were collected from water containers in a house of San Juan de Amancaes, located $180 \mathrm{~m}$ above sea level, $12^{\circ} 00^{\prime} 43.2^{\prime}$ 'S, $77^{\circ} 01^{\prime} 30.33^{\prime}$ ' $\mathrm{W}$. The immatures were kept in the Parasitology Laboratory, Instituto de Medicina Tropical "Daniel A. Carrion", Universidad Nacional Mayor de San Marcos (UNMSM), Lima, until adults started to emerged. Some larvae were preserved in $70 \%$ ethanol and 
mounted on microscope slides for identification. Both larvae and the four merged adults (two males and two females) were all identified as Ae. aegypti. The Ministry of Public Health was promptly informed of these findings.

On March 21, Ae. aegypti was found in 16 out of 20 inspected houses in San Juan de Amancaes. During this survey, an entomology team from the UNMSM collected a total of 83 Ae. aegypti (55 larvae, 20 pupae and 8 adults). Larval habitats included buckets, glass and plastic containers, flower vases, stoups located close to the houses, that contained relatively clean water, drawn from the local water supply, and often stored for domestic use for periods of five to ten days. In addition to Ae. aegypti, Culex quinquefasciatus larvae (48) and adults (3) were collected. On March 23 and 28, the survey was extended to Mariscal Castilla, Flor de Amancaes, El Altillo, Santa Rosa, Cerro Palomares, Villa Fatima, at two other sites (Club de Tiro and Club Revolver). All of these localities are part of the district of Rimac. We found 102 larvae, 67 pupae, and 14 adults of Ae. aegypti in houses located between 140 and $340 \mathrm{~m}$ above sea level. Ae. aegypti mosquitos were only found in the first four localities. Including the results obtained in San Juan de Amancaes the house index was 46.5\% (85/183). Again Cx. quinquefasciatus was also collected.

To date, Ae. aegypti have been collected from at least in 15 of the 24 Peruvian Departments. Given the potential risk for public health associated with pathogens (e.g. yellow fever, dengue viruses) transmitted by this mosquito, we recommend that
Ae. aegypti surveillance programs be expanded to determine the range of its distribution. Comprehensive vector and/or disease control programs with community participation, should be established to reduce the transmission risk and distribution of yellow fever and dengue present in other parts of Peru.

\section{ACKNOWLEDGMENTS}

To Nicolas Degallier (IDR, Paris, France), José Neyra R and Hugo Vizcarra F (Univ. Nac. Major de San Marcos, Lima, Perú), Julio Llancari (Minsterio de Salud de Perú) and Almeiro de Castro Gómez (Universidade de São Paulo, São Paulo, Brasil), for support with bibliographic material and for verifing the specimens of Aedes aegypti. To Lorenza Beati (Yale University, Connecticut, USA) by the suggestions and criticisms of the manuscript.

\section{REFERENCES}

Griffitts DHT 1934. Fiebre amarilla: importancia de algunas fases relativamente nuevas en relación con su profilaxia en los focos antiguos y nuevos. Bol Of Sanit Panam 13: 511-518.

Neyra Ramirez J, Sipán TF 1983. La fiebre amarilla pasado y presente en el Perú. Diagnóstico 12: 8696.

Oficina Sanitaria Panamericana 1949. Informe mensual sobre la campaña de erradicación del Aedes aegypti en los países americanos. Bol Of Sanit Panam 28: 62-66.

Roe C 1924. Conversando con el Dr Barton. Gac Méd Per 2: 2-5.

Severo OP 1958. Evolución de la campaña anti-Aegyti en los últimos diez años. Bol Of Sanit Panam 45: 375-386. 